\title{
Small quantities of erythrocyte bound immunoglobulins and autoimmune haemolysis
}

\author{
R J SOKOL, S HEWITT, D J BOOKER, R STAMPS \\ From the Regional Blood Transfusion Centre, Sheffield
}

SUMMARY Enzyme linked and radioimmune direct antiglobulin tests (DAGTs) were used to assess red cell bound IgG, IgA, and IgM in 585 patients referred to an immunohaematology reference centre. One hundred and fifty eight patients with $\leqslant 200 \mathrm{~mol} \mathrm{IgG}$ and small amounts of IgA and IgM coating their red cells were studied in detail. The presence of autoimmune haemolysis was determined from the clinical, haematological, and biochemical findings; it occurred in at least $25 \%$ of the 158 patients, the degree varying widely. There was a highly significant association between small increases in cell bound immunoglobulins and the presence of autoimmune haemolysis. Immunoglobulins of IgG, IgA, and IgM classes could produce autoimmune haemolysis when the classical agglutination DAGTs were negative; the IgA and IgM were usually found in association with IgG. The haemolytic effect was enhanced by the presence of complement and combinations of immunoglobulin classes on the red cells.

Autoimmune haemolysis is often associated with comparatively few positive serological findings, and the direct antiglobulin test (DAGT), using agglutination techniques, may be negative, ${ }^{1}$ one reason being that although significant amounts of immunoglobulins are bound to the red cells, the amounts are too low to be detected by classical methods. ${ }^{1}$ DAGTs, using enzyme linked ${ }^{2}$ and radioimmune techniques, ${ }^{3}$ have been introduced into routine use in this centre. These tests are of similar sensitivity in that they both detect immunoglobulin at levels found on the red cells of normal subjects; the enzyme linked test is used to detect IgG, IgA, and IgM and the radioimmune assay to quantitate IgG.

In the present study the occurrence of autoimmune haemolysis was assessed in patients with only small quantities of immunoglobulins coating their red cells.

\section{Material and methods}

The results of the serological investigations on all patients referred to our immunohaematology reference centre between January 11984 and December 311985 were examined. Samples were sent because of suspected or previous autoimmune haemolysis or because of difficulties caused by autoantibodies when grouping or cross matching. Five hundred and eighty five patients with a wide variety

Accepted for publication 6 October 1986 of conditions were seen during this period. Details of the investigations have been reported previously. ${ }^{24}$ Quantitative DAGT results were obtained for IgG only, usually by radioimmune assay, but in seven instances values were calculated from the result of the enzyme linked test using a correlation between the two techniques $(r=0.956){ }^{2}$ Cell bound $\mathrm{IgG}$ was considered to be raised if it was above $100 \mathrm{~mol} / \mathrm{red}$ cell. ${ }^{3}$ The enzyme linked tests, which assessed IgA and IgM as well as IgG, were considered to be positive when the optical density using patients' cells exceeded that of pooled 0 cells by $0 \cdot 2^{2}$; in the case of IgG the test became positive at about $110 \mathrm{~mol} / \mathrm{red}$ cell.

One hundred and fifty eight patients had $\leqslant 200$ of $\mathrm{IgG} /$ red cell and were selected for detailed study-this was irrespective of the IgA and IgM coating. The enzyme linked test showed that the amounts of $\operatorname{IgA}$ and IgM were also small and were rarely detected by the standard agglutination DAGT. The presence of haemolysis was determined from the clinical findings and results of laboratory investigations. ${ }^{5}$ These investigations included the haemoglobin concentration, reticulocyte count, blood film appearance, the presence of marrow erythroid hyperplasia, red cell lifespan, and measurement of serum haptoglobins, bilirubin and lactic dehydrogenase. The serological profile was not allowed to prejudice the decision.

The results of the enzyme linked DAGTs were used to examine the relation between small increases in red 
cell bound immunoglobulins (as judged by a positive test for $\operatorname{IgG}, \operatorname{IgA}$, or $\operatorname{IgM}$ ) and the presence of haemolysis. A $\chi^{2}$ test $^{6}$ was carried out and the confidence interval for the difference between the population proportions was calculated from the standard error of the difference. ${ }^{7}$

\section{Results}

The one hundred and fifty eight patients were divided into three main groups depending on the certainty with which autoimmune haemolysis could be ascribed. Patients with confirmed autoimmune haemolysis (irrespective of its severity) were placed in group 1 and those in whom haemolysis was absent or unlikely in group 3 . Group 2 contained cases in which the quantity and strength of available information did not permit a firm decision, but suggested that haemolysis was probable or possible. Group 3 included several patients undergoing routine follow up for previously diagnosed autoimmune haemolysis. Table 1 shows these groups and the results of the agglutination, radioimmune, and enzyme linked DAGTs. Subgroupings were made on the serological nature of the autoantibodies present. ${ }^{4}$ The strength of these autoantibodies varied; the reactions tended to be strong in patients with florid cold agglutinin disease, but were usually weak when warm reacting, particularly in patients in group 3 in whom haemolysis was absent or unlikely. "Associated disorders" (table 1) refers to those conditions where there is a predisposition for autoimmune haemolysis to develop, ${ }^{4}$ and "chronic disorders" to those in which a characteristic "sideropenic anaemia with reticuloendothelial siderosis" is commonly found ${ }^{8}$; the same types of disorder often feature in both categories. In the present study these conditions included acute and chronic infections, collagen and other immune based diseases (rheumatoid arthritis, systemic lupus erythematosus, scleroderma, ulcerative colitis, diabetes mellitus), neoplasia (acute myeloid and lymphocytic leukaemias, chronic lymphocytic leukaemia, nonHodgkin's lymphoma and carcinomata), myelodysplastic states, tissue disruption (chronic inflammation, trauma) and pregnancy.

Statistical analysis showed a highly significant association between small increases in cell bound IgG, $\operatorname{IgA}$, and IgM and the presence of haemolysis when patients in groups 1 and 3 were compared. There were also significant differences between groups 2 and 3 , but these were not found between groups 1 and 2 (table 2).

Table 1 Haemolytic state, serological findings, and results of direct antiglobulin tests

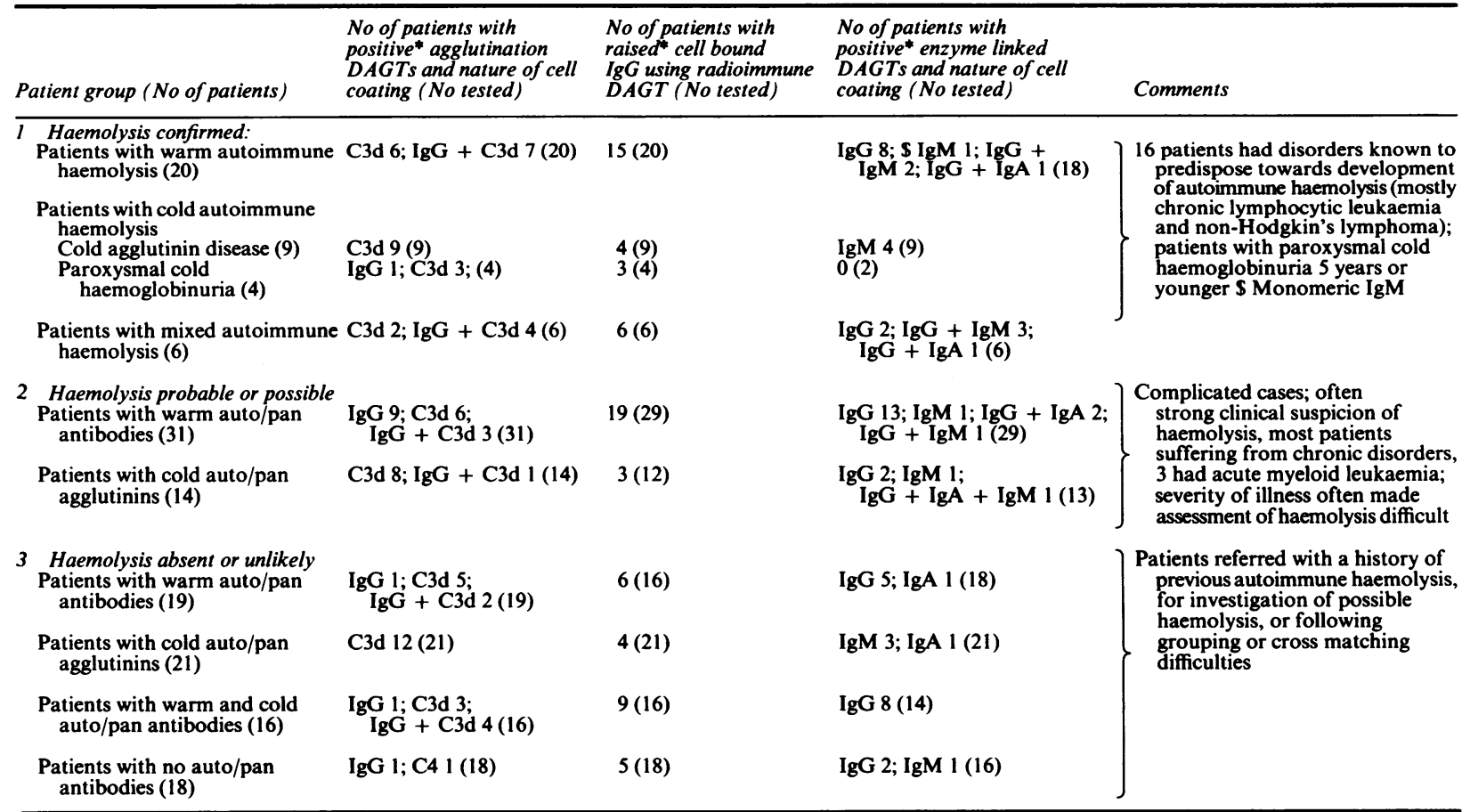

* Negative results or normal concentrations can be derived from No tested. 
Table 2 Statistical analysis comparing haemolytic state and small increases in cell bound $\operatorname{Ig} G, \operatorname{Ig} A$, and $\operatorname{Ig} M$, judged by positive enzyme linked $D A G T$ s

\begin{tabular}{llll}
\hline Patient group & \multicolumn{1}{l}{$\chi^{2}$} & pvalue & $\begin{array}{l}\text { Confidence interval } \\
(\%)\end{array}$ \\
\hline $1 v 3$ & 11.45 & $<0.001$ & 0.06 to $0.54(99)$ \\
$2 v 3$ & 5.12 & $<0.025$ & 0.01 to $0.39(99)$ \\
1 & 1.85 & $>0.1$ & \\
\hline
\end{tabular}

1 degree of freedom.

\section{Discussion}

The patients included in the present study form an important group, accounting for $27 \%$ of new cases referred to our immunohaematology laboratory. Previous reports have tended to select patients with obvious haemolysis and a negative agglutination DAGT $^{19-12}$ : these cases represent only the extreme of a spectrum of complicated clinical disorders, and to put them into perspective we looked for autoimmune haemolysis in all patients in whom the red cells were coated with $\leqslant 200 \mathrm{~mol} \mathrm{IgG} /$ cell, a value chosen to be at the borderline of sensitivity for the agglutination DAGT. Table 1 shows that haemolysis is common in such patients, certainly occurring in $25 \%$ (group 1) and probably in many more, if group 2 patients are considered. It also shows that the agglutination DAGT does not provide sufficient information to assist in the diagnosis and clinical management, and it emphasises the need to use the more sensitive tests. At their present stage of development we feel that both radioimmune and enzyme linked techniques are needed; they give similar results in individual cases, though slight variations around $100 \mathrm{~mol} \mathrm{IgG/red} \mathrm{cell} \mathrm{may} \mathrm{show} \mathrm{as} \mathrm{apparently}$ discrepant results (table 1).

The study had many problems. The degree of haemolysis varied considerably between patients: there was often difficulty in determining its presence, particularly if mild or compensated, or in patients with chronic disorders or serious conditions where the effect of blood loss, treatment, and blood transfusion had to be considered. In these cases haemolysis, even if present, was not the main clinical problem, and often only a limited number of the investigations listed in the material and methods section were carried out. Certain laboratory results must be considered with caution-low haemoglobin concentrations may be due to other causes, and normal haptoglobin concentrations and absence of reticulocytosis do not exclude haemolysis. ${ }^{5}$ Measurement of red cell survival (a definitive assessment of haemolysis) was rarely carried out. A "best decision" into which group to place the patient had therefore often to be made on limited data-hence the need for group 2 (table 1). The statistical analysis (table 2), however, indicates that this does not affect the overall findings of the study, group 2 showing a significant difference from group 3 but not from group 1 .

There was a highly significant association between small increases in cell bound immunoglobulins and the presence of autoimmune haemolysis (table 2). Correlation, however, was not absolute, the development of haemolysis depending on a complexity of interrelated factors. In patients with paroxysmal cold haemoglobinuria and cold agglutinin disease (table 1), small quantities of cold autoantibodies (of IgG and IgM classes, respectively) are known to activate complement, resulting in florid intravascular haemolysis; the cells remaining are coated with $\mathrm{C} 3 \mathrm{~d} .{ }^{13}$

In other instances (table 1) increased amounts of IgG were present on the red cells of patients with active autoimmune haemolysis, even though the agglutination DAGT for IgG was negative; these represent the classical "Coombs's negative" type of case. ${ }^{19}$ Although the rate of haemolysis generally corresponds to the amount of red cell bound IgG when larger quantities are entailed, ${ }^{14}$ the present findings show that the association is much more variable with small amounts, and other factors are clearly important: small quantities of IgG are known to activate complement, ${ }^{15}$ the effect of IgG being increased by the binding of $\mathrm{C} 3$ components, which significantly reduce the number of IgG molecules necessary to initiate haemolysis ${ }^{16}$; such cases are included in group 1 (table 1). Also shown (table 1) are examples where immunoglobulins of IgA and IgM classes helped to cause haemolysis, usually in association with IgG. Combinations of immunoglobulin classes, which are often detected when sensitive enzyme linked DAGTs are used, can act synergistically ${ }^{2}$; their presence is often associated with severe haemolysis. ${ }^{17}$ We consider that multiple immunoglobulin coating and the augmentation by complement were particularly important in producing haemolysis in the patients studied here (group 1, table 1).

Other factors known to be important in the development of haemolysis include IgG subclass and mononuclear phagocyte activity. ${ }^{13}$ No conclusions regarding IgG subclass could be drawn in the present study as the antisera currently available rarely give satisfactory results with small amounts of cell bound IgG. IgG3 is considered to be particularly liable to cause "Coombs's negative" autoimmune haemolysis, ${ }^{18}$ the Fc receptors on mononuclear phagocytes having a higher affinity for IgG3 than IgGl. ${ }^{19}$ We have seen, however, a healthy 19 year old blood donor with $2300 \mathrm{~mol} \mathrm{IgG3/red} \mathrm{cell} \mathrm{and} \mathrm{no} \mathrm{evidence} \mathrm{of}$ haemolysis. Tests for mononuclear phagocyte activity do not readily lend themselves to routine use and insufficient results were available for the present 
investigation. In previous reports enhanced function ${ }^{2021}$ and increased numbers of $\mathrm{Fc}$ receptors ${ }^{22}$ have been found in patients with autoimmune haemolysis; conversely, haemolysis may not be evident in patients with impaired reticuloendothelial function, even though their cells are coated with large amounts of $\mathrm{IgG}^{23}$

Other points of interest arose from the present study. Many patients were suffering from chronic disorders. The associated anaemia is known to have a haemolytic element, ${ }^{8}$ and the findings (table 1) suggest that increased cell bound immunoglobulins, as well as the increased reticuloendothelial function reported previously, ${ }^{8}$ may be responsible. Clearance of circulating immune complexes is a physiological function of red cells, ${ }^{24}$ and increased amounts of cell bound immunoglobulins may be due to immune complexes rather than to autoantibodies; this phenomenon has been particularly noted in patients with rheumatoid arthritis and systemic lupus erythematosus. ${ }^{25}$ Where patients with similar disorders in our series were investigated, however, and in another report of patients with systemic lupus erythematosus, ${ }^{15}$ red cell bound IgG was confirmed to be autoantibody by elution and readsorption on to normal cells. In several patients, particularly those in whom haemolysis was absent or unlikely (groups 3, table 1), increased plasma immunoglobulins may have produced non-specific adsorption on to the red cells. This finding has been described previously, serum concentrations sometimes being high enough to cause a positive agglutination DAGT. ${ }^{26}$ How nonspecific adsorption of IgG or binding of immune complexes affect erythrocyte survival is not known.

We thank Drs TE Bletcher, RM Hutchinson, Professor AG Johnson, Drs PAE Jones, ACK Lawrence, JS Lilleyman, S Mayne, F Murphy, WR Parry, S Sobolewski, KR Speed, A St J Wilding, DA Winfield and PJ Wyld for providing details of their patients; the Regional Blood Transfusion Centre, Manchester, for supplying radiolabelled anti-IgG: $\mathrm{Dr}$ W Wagstaff for helpful advice; and Mrs P Burke for secretarial help.

\section{References}

1 Gilliland BC. Coombs-negative immune hemolytic anemia. Semin Hematol 1976;13:267-75.

2 Sokol RJ, Hewitt S, Booker DJ, Stamps R. Enzyme linked direct antiglobulin tests in patients with autoimmune haemolysis. J Clin Pathol 1985;38:912-4.

3 Merry AH, Thomson EE, Rawlinson VI, Stratton F. A quantitative antiglobulin test for IgG for use in blood transfusion serology. Clin Lab Haematol 1982;4:393-402.

4 Sokol RJ, Hewitt S, Stamps BK. Autoimmune haemolysis: an 18 year study of 865 cases referred to a regional transfusion centre. Br Med J 1981;282:2023-7.
5 Petz LD, Garratty G. Acquired immune hemolytic anemias. New York: Churchill Livingstone, 1980:1-25.

6 Mack C. Essentials of statistics for scientists and technologists. New York: Plenum Press, 1967:95-105.

7 Gardner MJ, Altman DG. Confidence intervals rather than P values: estimation rather than hypothesis testing. $\mathrm{Br}$ Med $\mathrm{J}$ 1986;292:746-50.

8 Cartwright GE, Lee GR. The anaemia of chronic disorders. $\mathrm{Br} J$ Haematol 1971;21:147-52.

9 Gilliland BC, Baxter E, Evans RS. Red-cell antibodies in acquired hemolytic anemia with negative antiglobulin serum tests. New Engl J Med 1971;285:252-6.

10 Hershko C, Berrebi A, Resnitzky P, Eldor A. Relapsing haemolytic anaemia of pregnancy with negative antiglobulin reaction. Scand J Haematol 1976;16:135-40.

11 Petz LD, Garratty G. Acquired immune hemolytic anemias. New York: Churchill Livingstone, 1980:305-57.

12 Bodensteiner D, Brown P, Skikne B, Plapp F. The enzyme-linked immunosorbent assay: accurate detection of red blood cell antibodies in autoimmune hemolytic anemia. Am J Clin Pathol 1983;79:182-5.

13 Sokol RJ, Hewitt S. Autoimmune hemolysis: a critical review. Crit Rev Oncol Hematol 1985;4:125-54.

14 Rosse WF. Quantitative immunology of immune hemolytic anaemia. II. The relationship of cell-bound antibody to hemolysis and the effect of treatment. J Clin Invest 1971;50:734-43.

15 Gilliland BC, Leddy JP, Vaughan JH. The detection of cellbound antibody on complement-coated human red cells. J Clin Invest 1970;49:898-906.

16 Kurlander RJ, Rosse WF, Logue GL. Quantitative influence of antibody and complement coating of red cells on monocytemediated cell lysis. J Clin Invest 1978;61:1309-19.

17 Ben-Izhak C, Shechter Y, Tatarsky I. Significance of multiple types of antibodies on red blood cells of patients with positive direct antiglobulin test: a study of monospecific antiglobulin reactions in 85 patients. Scand J Haematol 1985;35:102-8.

18 Engelfriet CP, Von dem Borne AEG $\mathrm{Kr}$, Beckers D, et al. Immune destruction of red cells. In: Bell CA, ed. $A$ seminar on immune mediated cell destruction. Chicago: AABB, 1981:93-130.

19 Zupanska B, Thomson EE, Merry AH. Fc receptors for IgGl and IgG3 on human mononuclear cells - an evaluation with known levels of erythrocyte-bound IgG. Vox Sang 1986;50:97-103.

20 Kay NE, Douglas SD. Monocyte-erythrocyte interaction in vitro in immune hemolytic anemias. Blood 1977;50:889-97.

21 Gallagher MT, Branch DR, Mison A, Petz LD. Evaluation of reticuloendothelial function in autoimmune hemolytic anemia using an in vitro assay of monocyte-macrophage interaction with erythrocytes. Exp Hematol 1983;11:82-9.

22 Fries LF, Brickman CM, Frank MM. Monocyte receptors for the Fc portion of IgG increase in number in autoimmune hemolytic anemia and other hemolytic states and are decreased by glucocorticoid therapy. J Immunol 1983;131:1240-5.

23 Kelton JG. Impaired reticuloendothelial function in patients treated with methyldopa. New Engl J Med 1985;313:596-600.

24 Siegel I, Liu TL, Gleicher N. The red-cell immune system. Lancet 1981;ii:556-9.

25 Hansen OP. Simultaneous quantification of red cell and platelet surface-bound IgG \& IgM by an ELISA technique. Scand $J$ Clin Lab Invest 1984;44 (suppl 168):45-55.

26 Heddle NM, Turchyn KL, Kelton JG. Hypergammaglobulinemia can be associated with a positive direct antiglobulin test, a non-reactive eluate and no evidence of hemolysis. Transfusion 1985;25:451.

Requests for reprints to: Dr RJ Sokol, Regional Blood Transfusion Centre, Longley Lane, Sheffield S5 7JN, England. 